\title{
UTILIZATION OF DATE PALM POLLEN AS NATURAL SOURCE FOR PRODUCING FUNCTION BAKERY PRODUCT
}

FATMA M. I. SHAHIN

\author{
Food Technology Research Institute, ARC, Giza-Egypt
}

(Manuscript received 10 June 2014)

\begin{abstract}
In the present study, date palm pollen was studied as potential healthy ingredient for preparing the nutritional function butter cake. Polyphenols content from date palm pollen extract were fractionated using HPLC and the results reported that the date palm pollen had contained the highest content polyphenols compounds. Rutin, apgenin and coumarin were the highest amounts content $(15.43,12.26$ and $11.12 \%)$ followed by chlorogenic, $\mathrm{O}$ - cumaaric, gallic acid, quercetin and luteolin. Date palm pollen and its extract were added separately to wheat flour $72 \%$ at levels 3.0, 6.0 and $9.0 \%$ date palm pollen and their extract at 100,200 and $300 \mathrm{ppm}$ levels to give six blends, respectively. Date palm pollen (DPP) and wheat flour $72 \%$ extract and its blends were analyzed for their chemical constituents and minerals content. The results indicated that the DPP had contained the highest crude protein, lipid, ash and fiber $(32.95,19.31,4.17$ and $8.51 \%$, respectively) and when the DPP increased amount in the blends the chemical constituents increasing. The obtained results from the minerals composition of date palm pollen and wheat flour $72 \%$ extract and their blends revealed that the date palm pollen constitute of mineral. Sensory properties showed that the butter cake made from wheat flour $72 \%$ extract as a control had the highest degree (98.78\%) and the blends prepared by adding the natural antioxidant from date palm pollen at 100, 200 and 300 ppm were higher of sensory acceptance than butter cake made from 3, 6 and $9 \%$ date palm pollen. Peroxide value was determined in shortening which extracted from butter cake made from date palm pollen and their extract. Biological activity as total bacteria and fungi count were estimated in butter cake during storage period for four weeks. The results showed that the total count of bacteria for butter cake from DPP was ranged from 33.6 to $42.8 \times 10^{-6}$ CFU and their extract of DPP had contained 32.2 to $40.4 \times 10^{-6}$ CFU after four weeks and the total count of fungi was parallel to the bacteria count. It may be recommended that the date palm pollen rich in protein, lipid, and minerals content and natural antioxidant. Therefore, the addition of date palm pollen and their extract for butter cake effectively inhibited to increase in peroxide value and biological activity for four weeks period for producing function bakery product.
\end{abstract}

\section{INTRODUCTION}

Phoenix dactylifera $L$ (Date Palm) belong to family Arecaceae, called Nakhla and the Tree of Life by the Arabs. It is member of the monocotyledon family Arecaceae (Phillipson, 2001). 
The early Egyptians and ancient Chinese used date palm pollen as a rejuvenating medicinal agent .It has been called a fountain of youth. Pollen preparations are distributed worldwide for dietary purposes and as diet supplement by increasing the total dietary intake (Kroyer and Hegedus, 2001).

Date palm pollen application in the rites, and its uses in traditional and herbal medicine, has been recorded throughout history. Varity of pollen containing food products, such as candy and chocolate bars, are commercially available in health food stores in the Western world (Stanley and Linkens, 1974). They contain concentration of photochemical and nutrients and are rich in carotenoids flavonoids and phytosterols (Broadhurts, 1999). Moreover, they are good source of protein, amino acid, vitamins, dietary fiber, fatty acid, enzymes, hormones and minerals (Alferez and Campos, 2000).

Suspension of Phoenix dactylifera date palm pollen (DPP) is an herbal mixture that is widely used as a folk remedy for curing male infertility in traditional medicine Bahmanpour et al.. (2006). A thousand tones of DPP are produced every year by millions of palm trees grown in the Arabian region. DPP differed from bee pollen in that it is of a known source and its homogeneity, purity and is easily to be standardized. DPP was reported to have gonadal stimulating potency as well as fertility promotion in women in ancient Egypt Bajpayee (1997). It was reported that date pollen grain extracts contain estrogenic materials, estrone, as gonad-stimulating compounds that improve male infertility and exhibit gonadotrophin activity in the rat Dostal and Faber (1996). Cernilton is another pollen extract derived from several different plants in southern Sweden and has been known to be effective in the treatment of chronic a bacterial prostatitis and prostatodynia Ebeling (1986) and Buck and Rees (1989).

In addition to this, pollen also has high contents of polyphenolic substances, chiefly flavonoids with antioxidant (Kroyer and Hegedus, 2001) and antimicrobial activity (Basim et al.., 2006). During the last decade, interest in the study of phenolic compounds has increased greatly, mainly due to the antioxidant capacity of these substances in scavenging free radicals that are harmful to human health (Dorman et al.., 2003). Epidemiologic studies have also demonstrated positive correlation between the increase in phenolic compound consumption with antioxidant action (Javanmardi et al.., 2003) and reduction of the risk of cardiovascular diseases and certain types of cancer (Cook and Samiman, 1996).

The biological properties of phenolic compounds are related to the activity that each phenol exercises in a certain medium, and the chemical structure of flavonoids favors antioxidant action. The high capacity of the phenolic constituents to 
neutralize the species reactive to oxygen are strongly associated with their structure, such as conjugated double bonds and number of hydroxyls in the aromatic ring of flavonoids and cinnamic acid derivatives (Campos et al.., 1997). The radical DPPH is widely used to test the free radical scavenger capacity in apicultural products such as, pollen (Silva et al.., 2006; Leja et al.., 2007), propolis (Lu et al.., 2003; Kumazawa et al.., 2004) and honey (Meda et al.., 2005). The antioxidant activity using the stable free radical DPPH is based on the transfer of electrons from an antioxidant compound to a free radical, DPPH which, when it is reduced, loses its purple coloring. Thus, only the reducing power of the antioxidant is assessed, which becomes oxidized when it donates an electron, and for this reason does not detect pro-oxidant substances (Brand-Williams et al.., 1995).

The beneficial health and nutrition values of Phoenix dactylifera L. for human and animal consumption have been claimed for centuries (Barreveld, 1993). Experimentally, date extracts have shown to increase sperm count in guinea pigs; and to enhance spermatogenesis and increase the concentration of testosterone, follicle stimulating hormone (FSH), and luteinizing hormone (LH) in rats (El-Mougy et al.., 1991). The property of Date Palm pollen to increase serum testosterone level was evaluated in a parallel study (Iftikhar et al.., 2011).

The aim of this investigation is to utilize from date palm pollen as a powder and extract. Date palm pollen (DPP) is reached in antioxidant and these antioxidants were extracted and added to butter cake at levels 100, 200 and 300 ppm and its compared with butter cake made from DPP at levels 3, 6 and $9 \%$, respectively. Sensory properties and biological activity were determined.

\section{MATERIALS AND METHODS}

\section{Materials:}

The pollen grains of Egyptian date palm (Phoenix dactylifera L.) variety ElHayani was purchased from the Central Laboratory of Date Palm Research and Development, Agricultural Research Center, Giza- Egypt. The date palm pollen (DPP) grains were cleaned from the dust using air-dry and it's kept in a refrigerator at $5{ }^{\circ} \mathrm{C}$ till used.

Wheat flour $72 \%$ extraction (Triticum aestivum L.) was obtained from the North Flour Mills Company, Egypt.

Shortening (Rawaby consider refined palm oil, $100 \%$ pure vegetables oil and its cholesterol free) was obtained from Safola Egypt Company $10^{\text {th }}$ Ramadan City, Cairo. Skim milk, vanilla, sugar and baking power were purchased from local market. 


\section{Methods:}

\section{Fraction of polyphenols by HPLC for date palm pollen extract:}

Dried date palm pollen (100g) was finely powered and extracted with petroleum either $\left(40-60^{\circ} \mathrm{C}\right.$ ) to remove fats and any resinous materials. The residue was exhaustively extracting with one liter ethanol $70 \%$ by heating on a boiling water bath for six hours. Extraction was repeated until a color extract then the extracts were combined and concentrated to obtain aqueous ethanol extract and kept in a refrigerator at $6{ }^{\circ} \mathrm{C}$ till HPLC Technique analysis. High Performed Liquid Chromatography (HPLC) Model Hewlett Packard series 1100 (HP 1100) and Column which used hypersil BDS $5.0 \mu \mathrm{m} \mathrm{C} \mathrm{18.} \mathrm{Detector} \mathrm{UV} 254 \mathrm{~nm}$. Flow rate $0.3 \mathrm{~mL} / \mathrm{min}$. Mobile phase A: $(0.5 \mathrm{~mL}$ acetic acid/99.5 mL distilled water). B ( $0.5 \mathrm{~mL}$ acetic acid /99.5 mL acetonitrile). Temperature ambient at $25^{\circ} \mathrm{C}$ according to Merfort et al. (1997).

\section{Preparation and extraction of butter cake:}

The ingredients of raw materials (wheat flour $72 \%$ extraction, date palm pollen and extract of date palm pollen) were used in the preparation of butter cake according to Mizukoshi et al. (1979). Wheat flour $72 \%$ extraction (100gm.) mixed with $50 \mathrm{gm}$ shortening; $100 \mathrm{gm}$. sugar, $3.0 \mathrm{gm}$ baking powder, $75.0 \mathrm{~g}$. egg, $3.0 \mathrm{gm}$ vanilla and $7.0 \mathrm{gm}$ skim milk were added to give control. Date palm pollen and its extract were added separately to control at levels 3.0, 6.0 and $9.0 \%$ date palm pollen and their extract at 100, 200 and 300 ppm levels to give six blends, respectively.

\section{Chemical constituents of raw materials and its blends:}

Protein, total fat, ash and crude fiber were determined in raw materials (wheat flour $72 \%$ extraction and date palm pollen) and their blends according to the method outlined in AOAC (2005). Minerals content cupper (Cu), potassium (K), calcium (Ca), magnesium ( $\mathrm{Mg})$, iron (Fe), zinc ( $\mathrm{Zn}$ ) and manganese (Mn) were determined in the diluted solution of ash raw materials using the atomic absorption spectrophotometer (3300 Perkin-Elme) as described in by AOAC (2005) method.

\section{Organoleptically evaluation for different blends of butter cake:}

The butter cake blends were baked at $190^{\circ} \mathrm{C}$ for 25 minutes in an electric oven. Butter cake was allowed to cool on racks for about one hour before evaluation. The organoleptically evaluation for different blends of butter cake was estimated by ten experienced panelists according to AACC (2002). Also, shortening were extracted from butter cakes every week for four weeks by soaking n-hexan at room temperature for $48 \mathrm{hr}$. The extract was filtrated and evaporated from the solvent. Shortening was kept in deep freezer for further investigation. 
Peroxide value as phesico-chemical characteristics was determined in shortening which extracts from butter cake made from date palm pollen and their extract as millequivalent / kg oil according to AOAC (2005).

\section{Determination of microbiological analysis:}

Biological activity as total count of bacteria and fungi were estimated by the plate methods of Martin (1950) and Allen (1959) in butter cake which made from date palm pollen and its extract during storage at room temperature for four weeks. Plates of biological activity were incubated in incubator at $30^{\circ} \mathrm{C}$ for three days.

\section{Statistical analysis:}

The data obtained were analyzed by using SPSS statistical software (version 13 SPSS Inc., Chicago. USA). The results were expressed as mean \pm SD, and tested for significance using one-way analysis of variance "ANOVA" according to Armitage and Berry, (1987).

\section{RESULTS AND DISCUSSION}

\section{Polyphenols content in ethanol extract from date palm pollen.}

Polyphenols content from date palm pollen extract were fractionated using HPLC and the results are reported in Table (1). From the results it could be noticed that the date palm pollen had contained the highest content polyphenols. Rutin, apgenin and coumarin were the highest amounts content (15.43, 12.26 and 11.12\%) followed by chlorogenic, $\mathrm{O}$ - cumaaric, gallic acid, quercetin and luteolin were amounted 9.33, 9.05, 8.54, 8.15 and 8.04\%, respectively. Whereas, kaempferol and ferulic are presented in date palm pollen and also, the smallest amounts in date palm pollen were myricetin, $\mathrm{P}$ - cumaaric and naringin polyphenols.

Flavonoids present in plants possess diverse health benefits, which includes antioxidant and radical scavenging activities, reduction of certain chronic diseases, prevention of some cardiovascular disorders and certain kinds of cancerous processes (Tapas et al., 2008). Hong et al. (2006) assessed the flavonoid content in the Deglet Noor variety during the Khalal stage of maturity and identified 13 flavonoid glycosides of luteolin, quercetin and apigenin. Quercetin and luteolin formed primarily Oglycosidic linkages whereas apigenin was present as the C-glycoside. As of today, dates also have the unique distinction of being the only food to contain flavonoids sulfates (Hong et al., 2006). Chaira et al. (2009) recently reported that among the famous Tunisian dates, the highest content of flavonoids was present in the Korkobbi variety (54.46 quercetin equivalents $/ 100 \mathrm{~g}$ fresh weight). 
Table 1. Percent of polyphenols content in ethanol extract from date palm pollen.

\begin{tabular}{|l|l|l|}
\hline Compounds & Retention time & Date palm pollen \\
\hline Kaempferol & 36.286 & 6.54 \\
\hline Quercetin & 32.213 & 8.15 \\
\hline Naringin & 31.406 & 1.28 \\
\hline Apgenin & 29.368 & 12.26 \\
\hline Myricetin & 28.030 & 2.92 \\
\hline Coumarin & 25.718 & 11.12 \\
\hline O - Cumaaric & 25.243 & 9.05 \\
\hline Rutin & 24.006 & 15.43 \\
\hline Luteolin & 22.972 & 8.04 \\
\hline Ferulic & 22.465 & 5.00 \\
\hline P - Cumaaric & 21.025 & 2.34 \\
\hline Chlorogenic & 16.380 & 9.33 \\
\hline Gallic acid & 7.310 & 8.54 \\
\hline
\end{tabular}

\section{Chemical compositions of raw materials and their blends:}

Date palm pollen (DPP) and wheat flour $72 \%$ extract and its blends were analyzed for their constituents of crude protein, lipid, fiber, ash and total carbohydrates. The obtained data are given in Table (2) indicated that the DPP had contained the highest crude protein, lipid, ash and fiber (32.95, 19.31, 4.17 and $8.51 \%$, respectively). The blends made from wheat flour $72 \%$ extract fortified with 3, 6 and $9 \%$ date palm pollen, the results illustrated that when the DPP increased amount in the blends the chemical constituents increasing. Total carbohydrates were the highest amounted in wheat flour $72 \%$ extract $(82.79 \%)$. Whilst, the blends were decreased in total carbohydrates by increasing DPP due to the date palm pollen had contained the lowest total carbohydrates (35.06\%).

Dates fruits have high composition of carbohydrates, salts and minerals, dietary fiber, vitamins, fatty acids and amino acid gives a unique value in human nutrition Al-Shahib and Marshall (2003). Date palms play a significant role in neutralization of free radical and finally suppress the various types of diseases development and progression. Earlier investigation found that palm date has a potent ability to suppress free radicals Al-Farsi et al. (2005).

Table 2. Chemical compositions of raw materials and their blends (on dry weight basis).

\begin{tabular}{|c|c|c|c|c|c|}
\hline \multirow{2}{*}{$\begin{array}{c}\text { Chemical } \\
\text { analysis }\end{array}$} & $\begin{array}{c}\text { Date palm } \\
\text { pollen }\end{array}$ & Control & \multicolumn{3}{|c|}{ Blends } \\
\cline { 4 - 6 } & & $3 \%$ & $6 \%$ & $9 \%$ \\
\hline Protein & 32.95 & 12.69 & 13.10 & 14.69 & 15.30 \\
\hline Lipid & 19.31 & 2.13 & 2.93 & 3.63 & 4.33 \\
\hline Ash & 4.17 & 0.78 & 1.97 & 2.07 & 2.27 \\
\hline Fibers & 8.51 & 1.61 & 2.17 & 3.57 & 4.21 \\
\hline $\begin{array}{c}\text { Total } \\
\text { carbohydrates }\end{array}$ & 35.06 & 82.79 & 77.83 & 72.04 & 67.99 \\
\hline
\end{tabular}


The minerals composition of date palm pollen and wheat flour $72 \%$ extract and their blends are shown in Table (3). The obtained results revealed that the date palm pollen constitute a reach source of mineral elements. The predominant minerals copper $319.6 \mathrm{mg} / 100 \mathrm{~g}$ followed by zinc and manganese (309.4 and $284.0 \mathrm{mg} / 100 \mathrm{~g}$ ). Date palm pollen also contains useful amount of iron, potassium, magnesium and calcium (241.0, 160.0, 130.0 and $60.5 \mathrm{mg} / 100 \mathrm{~g}$, respectively). Moreover, wheat flour $72 \%$ extract had contained the highest amount of cupper $426.2 \mathrm{mg} / 100 \mathrm{~g}$ followed by manganese $219.0 \mathrm{mg} / 100 \mathrm{~g}$. Wherease, the blends were increased in minerals content by increasing addition of date palm pollen. Bacha et al. (1997) found that the pollen grains of date palm contain the macronutrients; $N$ was present in the highest concentrations, followed by $\mathrm{Ca}, \mathrm{P}, \mathrm{Mg}$ and $\mathrm{Na}$ of the micronutrients, Fe was present the highest concentrations followed by $\mathrm{Zn}, \mathrm{Mn}$ and $\mathrm{Cu}$.

Table 3. Minerals content of raw materials and its blends $(\mathrm{mg} / 100 \mathrm{~g})$.

\begin{tabular}{|c|c|c|c|c|c|}
\hline \multirow{2}{*}{$\begin{array}{c}\text { Minerals } \\
\text { content }\end{array}$} & \multirow{2}{*}{$\begin{array}{c}\text { Date palm } \\
\text { pollen }\end{array}$} & \multirow{2}{*}{ Control } & \multicolumn{3}{|c|}{ Blends } \\
\cline { 4 - 6 } & & $3 \%$ & $6 \%$ & $9 \%$ \\
\hline Cupper & 319.6 & 426.2 & 452.8 & 370.1 & 395.9 \\
\hline Potassium & 160.0 & 57.4 & 66.9 & 74.1 & 81.8 \\
\hline Calcium & 60.5 & 10.3 & 12.2 & 15.4 & 18.0 \\
\hline Magnesium & 130.0 & 26.1 & 31.6 & 36.7 & 41.2 \\
\hline Iron & 241.0 & 2.07 & 10.5 & 17.3 & 29.6 \\
\hline Zinc & 309.4 & 1.24 & 13.5 & 27.1 & 30.8 \\
\hline Manganese & 284.0 & 219.0 & 230.2 & 252.0 & 272.6 \\
\hline
\end{tabular}

Organoleptic evaluation of the butter cake made from date palm pollen:

Data obtained in Table (4) for sensory properties showed that the control sample of butter cake made from wheat flour $72 \%$ extract had the highest degree $(98.78 \%)$ of sensory acceptance. The same sensory acceptability resultant showed that in the butter cake made from wheat flour $72 \%$ extract and added the natural antioxidant from date palm pollen at 100, 200 and 300 ppm (95.44, 96.73 and 97.45 ppm, respectively). Sensory characteristics can be no variation by various concentrations of the ingredients in dough during production of butter cake prepared wheat flour $72 \%$ extract and it was added separetely 3, 6 and $9 \%$ date palm pollen were acceptable to most members regarding to taste, odor, texture, color and general appearance. 
Table 4. Effect of DPP and their extract on the sensory evaluation of butter cake

\begin{tabular}{|c|c|c|c|c|c|c|c|}
\hline $\begin{array}{l}\text { Types of } \\
\text { additions }\end{array}$ & $\begin{array}{l}\text { Taste } \\
20\end{array}$ & $\begin{array}{l}\text { Odor } \\
20\end{array}$ & $\begin{array}{c}\text { Texture } \\
15\end{array}$ & $\begin{array}{c}\text { Crust color } \\
15\end{array}$ & $\begin{array}{c}\text { Crumb } \\
\text { color } \\
15\end{array}$ & $\begin{array}{c}\text { General } \\
\text { Appearance } \\
15\end{array}$ & $\begin{array}{c}\text { Overall } \\
\text { acceptability } 100\end{array}$ \\
\hline Control & $\begin{array}{l}19.75^{\mathrm{a}} \\
\pm 0.56\end{array}$ & $\begin{array}{l}19.50^{\mathrm{a}} \\
\pm 0.13\end{array}$ & $\begin{array}{l}14.82^{\mathrm{a}} \\
\pm 0.66\end{array}$ & $\begin{array}{l}14.90^{\mathrm{a}} \\
\pm 0.11\end{array}$ & $\begin{array}{l}14.91^{\mathrm{a}} \\
\pm 0.80\end{array}$ & $\begin{array}{l}14.90^{\mathrm{a}} \\
\pm 0.65\end{array}$ & 98.78 \\
\hline 3 \% DPP & $\begin{array}{l}18.95^{\mathrm{a}} \\
\pm 0.06\end{array}$ & $\begin{array}{l}18.41^{\mathrm{ab}} \\
\pm 0.39\end{array}$ & $\begin{array}{l}14.23^{\mathrm{a}} \\
\pm 0.92\end{array}$ & $\begin{array}{l}12.85^{c} \\
\pm 0.78\end{array}$ & $\begin{array}{l}12.12^{\mathrm{c}} \\
\pm 0.07\end{array}$ & $\begin{array}{l}13.98^{\mathrm{b}} \\
\pm 0.66\end{array}$ & 90.54 \\
\hline 6 \% DPP & $\begin{array}{l}17.57^{\text {bc }} \\
\pm 0.23\end{array}$ & $\begin{array}{l}18.00^{b} \\
\pm 0.12\end{array}$ & $\begin{array}{l}14.35^{\mathrm{ab}} \\
\pm 0.28\end{array}$ & $\begin{array}{l}13.65^{\mathrm{b}} \\
\pm 0.48\end{array}$ & $\begin{array}{l}13.68^{\mathrm{b}} \\
\pm 0.09\end{array}$ & $\begin{array}{l}14.31^{\mathrm{ab}} \\
\pm 0.67\end{array}$ & 91.56 \\
\hline 9 \% DPP & $\begin{array}{l}19.15^{\mathrm{a}} \\
\pm 0.71\end{array}$ & $\begin{array}{l}18.87^{\mathrm{ab}} \\
\pm 0.44\end{array}$ & $\begin{array}{l}14.41^{a} \\
\pm 0.06\end{array}$ & $\begin{array}{l}13.12^{\mathrm{ab}} \\
\pm 0.85\end{array}$ & $\begin{array}{l}12.45^{c} \\
\pm 0.62\end{array}$ & $\begin{array}{l}14.35^{\mathrm{a}} \\
\pm 0.16\end{array}$ & 92.35 \\
\hline 100 ppm & $\begin{array}{l}18.40^{\mathrm{b}} \\
\pm 1.06\end{array}$ & $\begin{array}{l}19.10^{\mathrm{a}} \\
\pm 0.12\end{array}$ & $\begin{array}{l}14.25^{\mathrm{a}} \\
\pm 0.28\end{array}$ & $\begin{array}{l}14.70^{\mathrm{a}} \\
\pm 0.47\end{array}$ & $\begin{array}{l}14.42^{\mathrm{a}} \\
\pm 0.09\end{array}$ & $\begin{array}{l}14.67^{\mathrm{a}} \\
\pm 0.67\end{array}$ & 95.44 \\
\hline 200 ppm & $\begin{array}{l}19.00^{\mathrm{a}} \\
\pm 1.06\end{array}$ & $\begin{array}{l}19.10^{\mathrm{a}} \\
\pm 0.63\end{array}$ & $\begin{array}{l}14.32^{\mathrm{a}} \\
\pm 0.97\end{array}$ & $\begin{array}{l}14.80^{\mathrm{a}} \\
\pm 0.74\end{array}$ & $\begin{array}{l}14.63^{\mathrm{a}} \\
\pm 0.72\end{array}$ & $\begin{array}{l}14.88^{\mathrm{a}} \\
\pm 0.63\end{array}$ & 96.73 \\
\hline 300 ppm & $\begin{array}{l}19.30^{\mathrm{a}} \\
\pm 1.06\end{array}$ & $\begin{array}{l}19.20^{\mathrm{a}} \\
\pm 0.93\end{array}$ & $\begin{array}{l}14.35^{\mathrm{a}} \\
\pm 0.97\end{array}$ & $\begin{array}{l}14.80^{\mathrm{a}} \\
\pm 0.74\end{array}$ & $\begin{array}{l}14.89^{\mathrm{a}} \\
\pm 0.78\end{array}$ & $\begin{array}{l}14.91^{\mathrm{a}} \\
\pm 0.99\end{array}$ & 97.45 \\
\hline
\end{tabular}

\section{Effect of storage period on peroxide value in butter cake blends:}

The peroxide value is a good index for the quality of a fat. A refine fats should have peroxide value less than 1 millequivalent fat that have been stored for some period of time after refining may be found to have peroxide value of up to 10 millequivalent / kg oil (Rossell, 1983).

From the results in Table (5) it could be observed that the blends made from date palm pollen 6 and $9 \%$ and their extract at levels 200 and 300 ppm effectively inhibited to increase in peroxide value for four weeks period. Moreover, very close effects were observed for these blends. This means that date palm pollen and their extract contained antioxidants to which lipid peroxidation during storage.

Antioxidants are chemicals/materials that interact and deactivate the free radicals, therefore preventing them from causing harm. The prevention of actions of free radical is important step in the management of disease. Medicinal plants and their constituents play a vital and significant action to neutralize or inhibit the free radical 
by the use of antioxidant activity. Experimental studies support the role of reactive oxygen species in cancer and dietary antioxidants as well as endogenous antioxidants shows a vital role as cancer preventive agents via neutralization of reactive oxygen species Borek et al. (1986). Another study also showed that plant phenolic compounds including flavonoids are effective antioxidants with reported anti-mutagenic and anticarcinogenic effects Rice-Evans et al. (1997).

Table 5. Effect of storage period on peroxide value of butter cake blends.

\begin{tabular}{|l|l|l|l|l|l|l|l|}
\hline \multirow{2}{*}{$\begin{array}{l}\text { Storage } \\
\text { period/week }\end{array}$} & \multirow{2}{*}{ Control } & \multicolumn{3}{|l|}{ Blends made from DPP } & \multicolumn{3}{l|}{ Blends with its extract DPP } \\
\cline { 2 - 8 } & & $3 \%$ & $6 \%$ & $9 \%$ & $\begin{array}{l}100 \\
\mathrm{ppm}\end{array}$ & $\begin{array}{l}200 \\
\mathrm{ppm}\end{array}$ & $300 \mathrm{ppm}$ \\
\hline Zero & 2.12 & 2.12 & 2.12 & 2.12 & 2.12 & 2.12 & 2.12 \\
\hline One & 4.79 & 3.45 & 2.64 & 2.42 & 3.12 & 2.28 & 2.18 \\
\hline Two & 7.82 & 4.67 & 3.71 & 3.15 & 4.32 & 3.05 & 2.84 \\
\hline Three & 10.35 & 7.23 & 4.95 & 3.98 & 6.53 & 4.67 & 3.77 \\
\hline Four & 14.47 & 11.52 & 8.74 & 5.27 & 9.42 & 7.47 & 4.25 \\
\hline
\end{tabular}

\section{Biological activity in butter cake}

Microbiological spoilage is often the major factors limiting the shelf life of bakery products. Spoilage from microbial growth causes economic loss for both manufacturers and consumer. These losses could be due to many individual cases such as, packaging, sanitary practice in manufacturing, storage conditions and product turnover (Saranraj and Geetha 2012).

Biological activity as total bacteria and fungi count were estimated in butter cake with date palm pollen at levels at level 3,6 and $9 \%$ and their extract at 100, 200 and 300 ppm levels, respectively, during storage period for four weeks and the results are reported in Table 6 . The results showed that the total count of bacteria for butter cake from DPP was ranged from 33.6 to $42.8 \times 10^{-6} \mathrm{CFU}$ and their extract of DPP had contained 32.2 to $40.4 \times 10^{-6} \mathrm{CFU}$ after four weeks and the total count of fungi was parallel to the bacteria count. According to their results, it is clear that there were a positive relationship between these polyphenols and antimicrobial effects.

The phenols especially tannins have ability to form hydrogen bonds with carbohydrates and proteins by inhibition of some enzymes in the living cell leading to inhibit growth of microorganisms including pathogenic bacteria. Also the activity of phenolic compounds belongs to other chemical families abundant in phenols such as free phenols, tannins derivatives and flavonoids Reed (1995).

Mold growth is by far the major factor limiting shelf life of high and intermediate bakery products. In general, mold growth on bakery products is a 
serious problem that results in economic losses. Furthermore, losses of products due to mold spoilage are between 1 and 5 percent depending on the type of product, season, and the method of processing (Malkki and Rauha 2000).

Adjou et al. (2012) investigated the detection of spoilage fungi and mycotoxins contamination in butter cake product, popularly called "kulikuli". Forty five major markets were sampled and peanut cake products were analyzed. The results showed that the total coliform count ranged between $1.6 \times 10^{1}$ and $14.0 \times 10^{2} \mathrm{CFU}$ $\mathrm{g}^{-1}$, while the fungal count was ranged from 1.0 to $8.1 \times 10^{2} \mathrm{CFU} \mathrm{g^{-1 }}$ and total bacteria count was between from $5.4 \times 10^{4}$ to $1.4 \times 10^{6} \mathrm{CFU} \mathrm{g}^{-1}$. The high total bacterial and coliform count may have been as a result of the low level of hygiene maintained during the processing and sale of butter cake product. This includes the handlers, quality of ingredients used for dressing and the utensils. The open-air exposure of products, while they were displayed for sale, can also serve as source of contamination.

Table 6. Total bacteria and fungi count in butter cake made from date palm pollen during storage period

\begin{tabular}{|c|c|c|c|c|c|c|}
\hline \multirow{2}{*}{$\begin{array}{c}\text { Types of } \\
\text { additions }\end{array}$} & \multicolumn{2}{|c|}{ Total bacteria count $\times 10^{-6}$ CFU } & \multicolumn{3}{c|}{ Total fungi count $\times 10^{-2}$ CFU } \\
\cline { 2 - 7 } & One week & 2 weeks & 4 weeks & One week & 2 weeks & 4 weeks \\
\hline Control & 20.7 & 27.2 & 47.6 & 37.9 & 50.1 & 52.4 \\
\hline $3 \%$ DPP & 20.5 & 27.4 & 42.8 & 36.5 & 49.3 & 51.3 \\
\hline $6 \%$ DPP & 20.2 & 25.1 & 40.2 & 35.2 & 45.5 & 49.9 \\
\hline $9 \%$ DPP & 19.5 & 23.3 & 33.6 & 30.9 & 37.4 & 39.2 \\
\hline $100 \mathrm{ppm}$ & 19.8 & 25.4 & 40.4 & 35.3 & 46.5 & 49.8 \\
\hline $200 \mathrm{ppm}$ & 19.1 & 22.2 & 39.9 & 33.8 & 44.6 & 47.1 \\
\hline $300 \mathrm{ppm}$ & 18.7 & 21.5 & 32.2 & 29.5 & 36.9 & 37.4 \\
\hline
\end{tabular}

From the obvious results it may be concluded that the date palm pollen and its extract are rich in protein, minerals and other essential antioxidant which may prevent the oxidative damages of shortening and antimicrobial activity. The addition of date palm pollen and its extract to butter cake gave acceptability product, safe and high nutrition value and quality.

\section{REFERENCES}

1. AACC 2002. Approved Method of American Association of Cereal Chemist. Approved Methods, the AACC published by the American Association of Cereal Chemist. $13^{\text {th }}$, ed. St. Paul. Minn., USA.

2. Adjou, E. S., Yehouenou, B., Sossou, C. M., Soumanou, M. M ., and de Souza, C. A. 2012. Occurrence of mycotoxins and associated mycoflora in peanut cake product (kulikuli) marketed in Benin. African J. Biotechnol. , 11(78): 1435414360. 
3. Al-Farsi, M., Alasalvar, C., Morris, A., Baron, M. and Shahidi, F. 2005. Comparison of antioxidant activity, antho-cyanins, carotenoids, and phenolics of three native fresh and sun-dried date (Phoenix dactylifera L.) varieties grown in Oman. J Agric Food Chem; 53: 7592-7599.

4. Alferz, M. J. M. and Campos, M. S. 2000. Beneficial effect of pollen and or propels on the iron, calcium, phosphorus and magnesium in rats with nutritional ferropenic anemia. J.Agric. Food. Chem., 48:5715-5722.

5. Allen, O. M. 1959. Experiments in soil bacteriology in $1^{\text {st }} \mathrm{Ed}$. Burgess puplishing Co., Minneapolis, Minnesota.

6. Al-Shahib, W. and Marshall, R. J. 2003. The fruit of the date palm: Its possible use as the best food for the future. Int J Food Sci Nutr; 54: 247-259.

7. AOAC (2005). Accosation of Official Analytical Chemists. Official Methods of Analysis $17^{\text {th }}$ ed. AOAC. Arlington, Virginia, 2220 USA.

8. Armitage, P and Berry, G. 1987. Statistical Method in Medical Research. Blackwell, Oxford, UK, 1987; PP: 93-213.

9. Bacha, M. A., Ali, M. A. and Farahat, F. A. 1997. Chemical composition of pollen grains of some date palm males grown in Riyadh, Saudi Arabia. Arab Gulf. J. Scientific Res., 15(3): 783-803.

10. Bahmanpour. S., Talaei, T., Vojdani, Z. and Panjehshahin, M. R. 2006. Poostpasand A, Zareei S, Ghaeminia M: Effect of Phoenix Dactylifera Pollen on Sperm Parameters and Reproductive system of Adult Male Rats. Iran J Med Sci, 31:208-212.

11. Bajpayee, K. K. 1997. Ethnobotany of Phoenix (Arecaceae). JETB, 21:155-157.

12. Barreveld, W. 1993. Date palm products. Rome, Italy, FAO.

13. Basim, E., Basim, H. and Ozcan, M. 2006. Antibacterial activities of Turkish pollen and propolis extracts against plant bacterial pathogens. Journal of Food Engineering, Oxford, 77, 3, 992-996.

14. Borek C, Ong A, Mason H, Donahue L and Biaglow JE. 1986. Selenium and vitamin $E$ inhibit radiogenic and chemically induced transformation in vitro via different mechanisms. Proc Nat Acad Sci U S A 1986; 83: 1490-1494.

15. Brand-Williams, W., Cuveller, M. E., Berset, C. 1995. Use of free radical method to evaluate antioxidant activity. LWT- Food Science and Technology, Zurich, 28, 5, 25-30.

16. Broadhurt, C. L. 1999. Bee products: medicine from the live. Nutr. Sci. News, 4:366-368.

17. Buck, A. C. and Rees, R. W. M. 1989. Ebeling L: Treatment of chronic prostatitis and prostatodynia with pollen extract. $\mathrm{Br}$ J Urol, 64:496-499. 
18. Campos, M. G., Markham, K. R., Mitchell, K. A. and Cunha, A. P. 1997. An approach to the characterization of bee pollens via their flavonoid/phenolic profiles. Phytochemical Analysis, Hoboken, 8, 4, 181-185.

19. Chaira, N., Smaali, M. I., Martinez-Tomé, M., Mrabet. A., Murcia, M. A., and Ferchichi, A. 2009. Simple phenolic composition, avonoid contents and antioxidant capacities in water-methanol extracts of Tunisian common date cultivars (Phoenix dactylifera L.). Int. J. Food Sci. Nutr., 60: 316-329.

20. Cook, N. C. and Samman, S. 1996. Flavonoids - chemistry, metabolism, cardioprotective effects, and dietary sources. Journal of Nutritional Biochemistry, Lexington, 7, 2, 66-76.

21. Dorman, H. J. D., Kosar, M., Kahlos, K., Holm, Y. and Hiltunen, R. 2003. Antioxidant properties and composition of aqueous extracts from Mentha species, Hybrids, Varieties, and Cultivars. Journal of Agricultural and Food Chemistry, Washington, 51, 16, 4563-4569.

22. Dostal, L. A. and Faber, C. K. 1996. Zandee J: Sperm motion parameters in vas deferens and cauda epididymal rat sperm. Reprod Toxicol, 10:231-235.

23. Ebeling, L. 1986. Therapeutic results of defined pollen extract in patients with chronic prostatitis or BPH accompanied by chronic prostatitis. In Therapy of prostatitis. Edited by: Schmiedt E, Alken JE, Bauer H W. Zuckschwerdt Verlag, MiInchen;:154-160.

24. El-Mougy, S., Abdel-Aziz, S., Al-Shanawany, M. and Omar, A. 1991. The gonadotropic activity of palmae in mature male rats. Alexandria J. Pharmacol. 5:156-159.

25. Hong, Y. J., Tomas-Barberan, F. A., Kader, A. A. and Mitchell, A. E. 2006. The flavonoid glycosides and procyanidin composition of Deglet Noor dates (Phoenix dactylifera). J. Agric. Food Chem. 54: 2405-2411.

26. Iftikhar, S., Bashir, A., Anwar, M. S., Mastoi, S. M. and Shahzad, M. 2011. Effect of date palm pollen (dpp) on serum testosterone levels in prepubertal albino rats. Pak. J. Med. Health Sci. 6(4):639-644.

27. Javanmardi, J., Stushnoff, C., Locke, E. and Vivanco, J. M. 2003. Antioxidant activity and total phenolic content of Iranian Ocimum accessions. Food Chemistry, Oxford, 83, 4, 547-550.

28. Kroyer, G. and Hegedus, N. 2001. Evaluation of bioactive properties of pollen extracts as functional dietary foods supplements. Innovative Food Sci . Emerging Technol., 2(3): 171-174.

29. Kumazawa, S., Hamasaka, T. and Nakayama, T. 2004. Antioxidant activity of propolis of various geographic origins. Food Chemistry, Oxford, 84, 3, 329-339. 
30. Leja, M., Mareczka, A., Wyzgolik, G., Klepacz-Banika, J. and Czekonska, K. 2007. Antioxidative properties of bee pollen in selected plant species. Food Chemistry, Oxford, 100, 1, 237-240.

31. Lu, L. C., Chen, Y. W. and Chou, C. C. 2003. Antibacterial and DPPH free radical-scavenging activities of the ethanol extract of propolis collected in Taiwan. Journal of Food and Drug Analysis, Taiwan, 11, 1, 277-282.

32. Malkki, Y. and Rauha, O. 2000. Mould inhibition by aerosols. Baker's Digest., 52: 47-50.

33. Martin, J. P. 1950. Use acid rose Bengal and streptomycin in plate method for estimating soil fungi. Soil Sci., 69: 215-232.

34. Meda, A., Lamien, C. E., Romito, M., Milligo, J. and Naculma, O. G. 2005. Determination of the total phenolic, flavonoid and proline contents in Burkina Fasan honey, as their radical scavenging activity. Food Chemistry, Oxford, 91, 3, 571-577.

35. Merfort, I., Wray, V., Barakat, H. H., Hussen, S. A. M., Nawwar, M.A. M. and Willuhan, G. 1997. Flavonol triglyosides seeds of Nigella sativa. Phytochem., 46(2): 359-363.

36. Mizukoshi, M., Kawada, T. and Mastsui, N. 1979. Model studies of cake baking.1: continuous observations of starch gelatinization and protein coagulation during baking. Cereal Chem., 56(4):305-310.

37. Phillipson, J.D. 2001. Phytochemistry and medicinal plants. Phytochemistry $.56: 237-243$.

38. Reed, J. 1995. Nutritional toxicology of tannins and related polyphynols in Forage legumes. J. Animal Soc., 73: 1516-1528.

39. Rice-Evans CA, Miller NJ and Paganga G. 1997. Antioxidant properties of phenolic compounds. Trends Plant Sci 1997; 2: 152-159.

40. Rossell, J. B. 1983. In rancidity in food, (Allen, J.C. and R.J Hamilton). Applied Sci. Publishers, pp. 21-47.

41. Saranraj, P. and Geetha, M. 2012. Microbial spoilage of bakery products and its control by preservatives. Intern. J. Pharm. and Biol. Archives, 3(1):38-48.

42. Silva, T. M. S., Camara, C. A., Lins, A. C. S., Barbosafilho, J. A., Silva, S. E. M., Fretitas, B. M. and Santos, F. A. B. 2006. Chemical composition and free radical scavenging activity of pollen loads from stingless bee Melipona subnitida Ducke. Journal of Food Composition and Analysis, Rome, 19, 6, 507-511.

43. Stanley, R. G. and Linkens, H. G. 1974. Pollen, Biology, Biochemistry Management. Springer -Verleg Berliin Heidelberg, New-York,P.44.

44. Tapas, A. R., Sakarkar, A. M. and Kakde, R. B. 2008. Flavonoids as neutraceutical: A review. Trop. J. Pharmaceut. Res. 7: 1089-1099. 


\section{الإستفادة من حبوب لقاح نخيل البلح كمصدر \\ طبيعى فى إنتاج مخبوزات وظيفية}

\section{فاطمة محمد شاهين}

$$
\text { معهد بحوث تكنولوجيا الأغذية- مركز البحوث الزراعية- جيزة- مصر }
$$

تمت الدراسة على حبوب لقاح نخيل البلح من الناحية الصحية لأعداد كيك دسم غذائى .

مستخلص حبوب لقاح نخيل البلح يحتوى على فينو لات عديدة وتم تفريدها بو اسطة جهاز ال HPLC

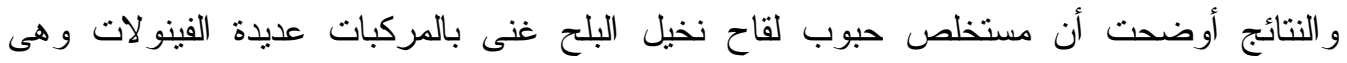

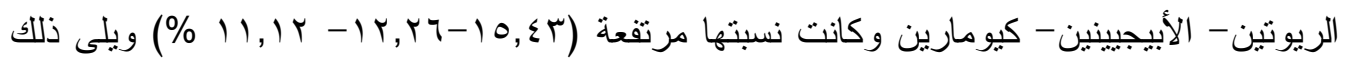
كلوروجنيك - أرثوكيو ماريك- حامض الجاليك- الليتولين.

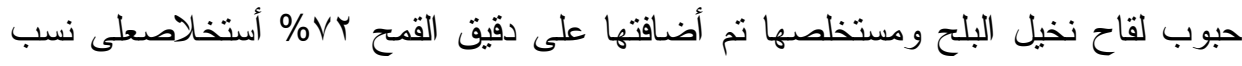

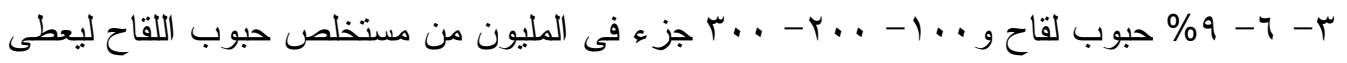

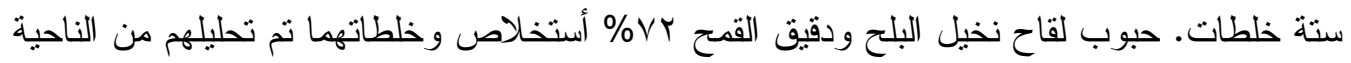
الكيماوية و ومتوى المعادن. أثنارت النتائج الى أن حبوب لقاح نخيل البلح كانت مرتفعة فى نسبة

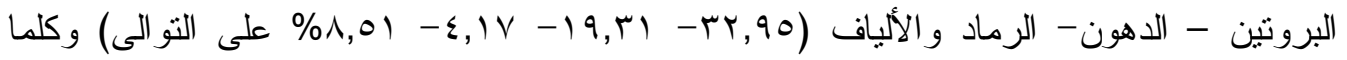
زادت كمية حبوب اللقاح فى الخلطات زادت نسبة التركيب الكيماوى. النتائج الأتية من تحليل محتو المعادن لحبوب لقاح نخيل البلح ودقيق القمح وخلطاتهم وجد أن حبوب اللقاح مرتفعة فى نسبة

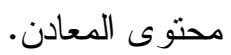

الصفات الحسية بالنسبة للكيك الدسم المجهز بواسطة دقيق القمح \&Yr\% أستخلاص كعينة

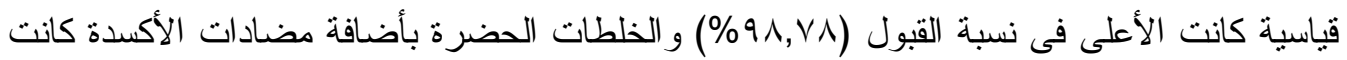

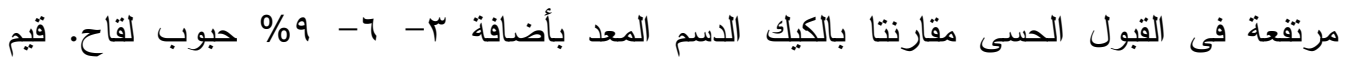
البيروكسيد نم تقدير ها فى الثورتننج المستخلص من الكيك الدسم المحضر بواسطة حبوب اللقاح ومستخلصها. النشاط الحيوى وهو عد البكتربا و الفطريات فى الكيك الدسم أثناء فترة التخزين لمدة أربعة أسابيع. أوضحت النتائج أن عد البكتريا فى الكيك الدسم الدحضر من حبوب لقاح نخيل البلح ينز اوح

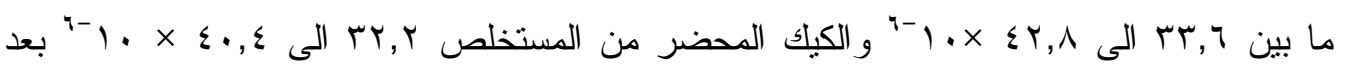

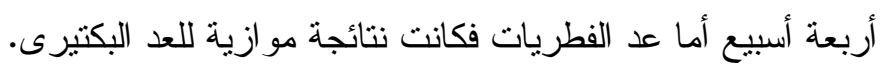

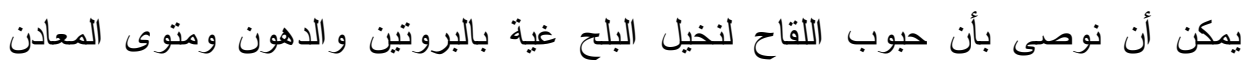
ومضادات الأكسدة الطبيعية. لذلك أضافة حبوب اللقاح ومستخلصها الى الكيك الدسم يعمل على تقليل فعل الأكسدة و النشاط الحيوى أثناء فترة التخزين وذلك لأنتاج مخبوز ات غذائية وظيفية. 